\title{
An investigation into the disciplinary methods used by teachers in a secondary township school in South Africa
}

\author{
Authors: \\ Nomvula J. Serame ${ }^{1}$ \\ Izak J. Oosthuizen ${ }^{2}$ \\ Charl C. Wolhuter \\ Connie B. Zulu ${ }^{2}$
}

\section{Affiliations:}

${ }^{1}$ School of Education,

North-West University,

Potchefstroom Campus,

South Africa

${ }^{2}$ School of Education, NorthWest University, Mafikeng

Campus, South Africa

\section{Correspondence to: \\ Charl Wolhuter}

Email:

charl.wolhuter@nwu.ac.za

Postal address:

Private Bag X6001,

Potchefstroom 2520,

South Africa

Dates:

Received: 30 Nov. 2012

Accepted: 26 July 2013

Published: 12 Nov. 2013

Republished: 06 Feb. 2014

How to cite this article: Serame, N.J., Oosthuizen, I.J., Wolhuter, C.C. \& Zulu, C.B., 2013, 'An investigation into the disciplinary methods used by teachers in a secondary township school in South Africa', Koers - Bulletin for Christian Scholarship 78(3), Art. \#450, 6 pages. http://dx.doi.org/10.4102/ koers.v78i3.450

Note:

Article republished with updated author information of Nomvula J. Serame.

\section{Copyright:}

(C) 2013. The Authors.

Licensee: AOSIS

OpenJournals. This work

is licensed under the

Creative Commons

Attribution License.

\section{Read online:}

The research that this article reports on investigated the incidence of learner discipline problems, the effect of them on teachers, the teachers' methods of maintaining discipline and the effectiveness of those methods in one township, namely Jouberton in Klerksdorp, South Africa. The experiences of both teachers and learners were surveyed. It was found that discipline at the school is far from satisfactory and problems with discipline are more serious than the international norm indicates. These problems have a serious effect on a large part of the teachers' family life, personal health, job satisfaction and morale. Whilst both teachers and learners commendably prefer the educationally sound preventive and positive methods of maintaining discipline, the application of these methods appears not to be effective: it seems as if teacher education falls short in the area of maintaining discipline, particularly regarding the successful application of proactive methods of maintaining discipline. Finally, the learners' views on the maintenance of discipline are an alarming indictment of the principles of democracy, human rights and human dignity, and of rationality as a tool for conflict resolution. Recommendations are made for follow-up research with the objective of amelioration.

'n Ondersoek na die dissiplinemetodes wat gebruik word deur sekondêre skoolonderwysers in Suid-Afrika. Die navorsing waaroor hier gerapporteer word, het ondersoek ingestel na die voorkoms van leerderdissiplineprobleme, die effek daarvan op onderwysers, onderwysers se metodes om dissipline te handhaaf, en die doeltreffendheid van dié metodes, soos dit voorkom in 'n historiese Swart woonbuurt, naamlik Jouberton, Klerksdorp, Suid-Afrika. Die belewenis van onderwysers sowel as leerders was gepeil. Daar is bevind dat dissipline by die skool ver van bevredigend is en dat dissiplineprobleme ernstiger is as die internasinoale norm. Hierdie probleme het ernstige gevolge op 'n groot persentasie van onderwysers se persoonlikie lewe, werksbevrediging en moraal. Terwyl dit prysenswaardig is dat beide onderwysers en leerders die opvoedkundig meer aanvaarbare voorkomende en positiewe metodes van dissiplinehandhawing verkies, blyk dit dat dat onderwysers nie daarin slaag om dié proaktiewe metodes van dissiplinehandhawing suksesvol toe te pas nie. Laastens dui leerders se mening oor metodes van dissiplinehandhawing op 'n kommerwekkende minagting van die beginsels van demokrasie, menseregte en menswaardigheid, en van rasionaliteit as instrument in konflikresolusie. Aanbevelings vir opvolgnavorsing ter verbetering van die dissiplinesituasie aan skole word gemaak.

\section{Introduction}

At present, learner misconduct appears to be of great concern in the arena of public education. An orderly learning and teaching environment is a prerequisite for optimal teaching and learning in class. The disorder and disruption that often results from learner misconduct is currently having a detrimental effect on effective teaching and learning. Although much research in this area has been conducted worldwide, little has so far been conducted in South African township schools.

\section{Problem statement}

There appears to be concern worldwide about the state of learner discipline and about learner misconduct in schools (Russo, Oosthuizen \& Wolhuter 2013). In England and Wales, for example, government statistics published showed that the government school inspectors (in Ofsted, the Office for Standards in Education, Children's Services and Skills) judged pupil behaviour in $18.4 \%$ of secondary schools as either satisfactory or inadequate. In $0.1 \%$ of secondary schools, it was judged to be inadequate, the lowest descriptor used by the inspectorate. ${ }^{1}$ The government minister responsible for schools said that he was 'concerned' that almost one in five secondary schools were rated no better than satisfactory in respect of behaviour (Department of Education, England and Wales 2011). In Australia, a recent media report based on information obtained under the country's Freedom of Information legislation reported that in the state of South Australia alone the cost of repairing vandalism was $\$ 6.3$ million in 2010 (Keller 2011). In China, according 
to one survey of 527 teachers from 27 elementary schools located in five provinces, about $45 \%$ of the teachers reported spending 'too much time' on students' behavioural problems (Shen et al. 2009:187). South Africa has not been spared this problem either (Wolhuter, Oosthuizen \& Van Staden 2010): a study by the South African Human Rights Commission in 2008 on school-based violence has confirmed media reports and complaints from educators that violence in many South African schools has reached alarming proportions (South African Human Rights Commission [SAHRC] 2008:1; Wolhuter \& Steyn 2003). In order to establish and maintain a disciplined and purposeful environment for effective education and learning in schools, educators need to apply effective disciplinary methods.

Wolhuter and Van Staden's (2008:25) empirical research confirmed that South African educators face a variety of forms of learner misconduct. Most educators face the following forms of misconduct daily: disruptive behaviour, obscene language, impertinence, untidy or incorrect attire, neglect of duty, the telling of lies and absence from school. Most educators face ill-manneredness, tardiness and bullying weekly. Dishonesty, moodiness, provocative behaviour, disrespect for educators, vandalism and theft are forms of misconduct most educators have to deal with monthly, whilst most educators reported that they experienced graffiti written by students annually. What is cause for even more concern is the effect of learner discipline problems on educators reported in the same study. Eighty-five percent of the educators in the study reported that learner discipline problems had caused them, at times or regularly, to be unhappy in their work, 58\% that it had caused tension, sometimes or regularly, in their family lives, and $54 \%$ that it had caused health problems in the educators (Wolhuter \& Van Staden 2008:390). It seems that whilst learner discipline does constitute a problem in schools, it is the relatively minor forms of misbehaviour which dominate. Serious misconduct, that is, those forms of misconduct constituting criminal offences, occurs more rarely, namely monthly. The international pattern is also that minor forms of ill-discipline occur frequently; serious forms of malbehaviour are rare (Wolhuter \& Steyn 2003; Shen et al. 2009; Upindi 2012).

Whilst learner discipline problems in South African schools and their handling have been researched many times before, the unique contribution of this research is its particular focus on a township school. The unique ecology of township schools makes applications of, or extrapolations from, research done in other South African schools problematic. This was also, as far as could be ascertained, the first time that research had brought together in one study both learners' and educators' perceptions and experiences of discipline problems in South African schools as well as views about the effectiveness of the methods applied to maintain discipline in schools.

The theory behind the investigation is rooted in a Christian worldview. The Hebrew concepts of discipline are yasar and musar, which refer to instruction, chastisement, discipline and correction. The Greek equivalent of the Hebrew word yasar is paideuo (Renn 2005:174, 285). Paideuo also means to chastise, instruct and learn. The word also connotes the training of a child (Vines 1985:97). Related to this word is the Greek word paidagogos, which, amongst other things, means instructor or schoolmaster. It occurs in 1 Corinthians 4:15 and Galatians 3:24 and 25 (Strong 1995:66). Originally, the main duties of a paidagogos were to accompany a boy to school in order to watch over his safety and to train him in morals, manners and good deportment (Barclay 1974:206). The paidagogos was usually a trusted elderly man with exemplary behaviour worthy of emulating.

At the one end of the continuum, the concept of 'discipline' implies a strict approach, as depicted in 1 Timothy 1:20, where Paul calls on Timothy to discipline Hymenaeus and Alexander for blaspheming. At the other end of the continuum, in 2 Timothy 2:25, Paul asks Timothy to approach his opponents in a gentle way, whereas in Titus 2:12 he refers to the fact that by God's grace we are taught to renounce our ungodliness. It becomes clear that from a Christian perspective there is no disciplinary measure emanating from God if it 'does not take its source in love and is not aimed at good' (Barclay 1976:179). The latter approach therefore signifies that, when disciplining a child, the ultimate Christian approach for teachers and parents has to be that of training or correcting the child's behaviour, keeping a beneficent end result in mind.

The aim of the research reported in this article was to investigate educators' methods of maintaining discipline in one township, namely Jouberton in Klerksdorp. In fulfilment of this aim, the remainder of this article is structured as follows. The next section contains the conceptual and theoretical framework on which the empirical investigation was based. That is followed by a report on the empirical investigation, an outline of the findings, and a discussion of them. The article concludes with a number of recommendations.

\section{Conceptual-theoretical framework}

Grootman (2003) defines discipline (in the context of education) as the means to help children develop selfcontrol, to motivate them, and to assist them so that they feel good about themselves and develop higher-level thinking skills. Butterfield (2003:472) defines 'discipline' as training and self-control in compliance with rules and authority; the state of improving behaviour resulting from such training or situation; punishment or reprimand, or a classification of rules of behaviour and methods of practice. Mabeba and Prinsloo (2000:34) contend that discipline refers to learning orderliness, guidance and regulated scholarship. Taking into account all of these definitions, it could be said that discipline is developing self-control and acquiring the skills required for living in harmony with other people.

The research was rooted in the theoretical-philosophical framework of the German concept geborgenheit. In general terms, the word geborgenheit can be translated as security or safety (Scholze-Stubenrecht et al. 2005:721), a translation that does not really depict the full meaning of the German word. 
In addition, it is more in the etymological root of geborgenheit - bergen - that we find the application of geborgenheit to education. The infinitive bergen means: to hide, to shelter, to conceal, to shield or to place in safety (Betteridge 1978:78). One of the essential requirements of the best possible education for children is an environment of mental and physical safety - an environment that shelters the child from disorderly and harmful distractions, disruptions and intrusions. Heidegger (2005:235) describes the whole of mankind, unlike the rest of creation, as threatened entities in need of defence. Furthermore, unlike other forms of life, the child does not enter the world as a complete being; consequently, it is in need of physical and mental protection in order to develop (Oberholzer 1968:314).

One of the vital educational spaces in need of geborgenheit is the teaching and learning environment: Order and tranquility should reign in this space. Disorderly and disruptive conduct obstructs optimal teaching and learning. A great deal of research shows the negative influence of misconduct on teaching and learning in the classroom (De Wet \& Jacobs 2009:52). Since there is a strong link between well-behaved classes and successful teaching (Morin \& Battalio 2004:252, cited in De Wet \& Jacobs 2009:52), it is essential for the teacher to maintain a state of orderly geborgenheit in the classroom environment, and this can only be done by applying the appropriate disciplinary methods.

According to South African common law, teachers also hold an in loco parentis [in the place of a parent] position in terms of which they have a duty of care to ensure the safety of learners under their supervision (Oosthuizen et al. 2009:62, 125).

Certain other statutory provisions specifically focus on the safety of the child, whereas other forms of legislation broadly focus on creating an orderly legal equilibrium amongst legal subjects. Such legal directives as focus on the safety of the child have been taken up by the South African Council for Educators Act of 2000 and are also reflected in the Child Care Act of 1983. The Children's Act of 2005 embodies the general need of the child for geborgenheit.

A number of the constitutional rights of learners are also important when considering disciplinary proceedings against a learner. In terms of section 9(10a) of the Constitution of the Republic of South Africa (South Africa 1996[a]), every learner is granted the right to a basic education. Section 28 of the Constitution focuses on children's rights: s. 28(2) emphasises that the child's best interests must be taken into consideration in every matter concerning a child. Section 10 states that everyone has inherent dignity and the right to have their dignity respected and protected. In terms of s. 12, learners have the right to freedom and security of person: that is, they have the right not to be subjected to any form of forcefulness, either in any private or in any public place or on their body. Learners may not be punished in a harsh, heartless or humiliating way (South Africa 1996[a]). Section 14 states that the child's right to privacy should be respected and protected.
In addition to all of the above, various provisions of the South African Schools Act (South Africa 1996[b]) are relevant when dealing with learner misconduct. Sections 8-10 of the Act deal with the drafting of a code of conduct for a school, the suspension and expulsion of a learner, and corporal punishment.

When considering possible methods of maintaining discipline in schools, a core document is also the United Nations Convention of the Rights of the Child (United Nations 1989), to which South Africa is a signatory. Article 3(1) of this Convention explains that parties should ensure that the best interests of the child become a primary concern for public or private social welfare institutions, courts of law, administrative authorities and legislative bodies. Article 3(2) indicates that parties should attend to the protection, care and welfare of the child, and take into consideration the rights and duties of the child's parents, legal guardians or other individuals legally responsible for the child, and should take all appropriate legislative steps to meet these requirements. Article 19 of the Convention states that parties must take all proper legislative, administrative, social and educational action to protect the child from all forms of physical or mental violence, injury or abuse, neglect or negligent treatment, maltreatment or exploitation, including sexual abuse, whilst the child is in the care of a parent or parents, guardian or any other person who has responsibility for their upbringing. Article 28(2) stipulates that parties should consider all proper measures to ensure that school discipline is applied fairly and that the child's human dignity is respected, in compliance with the stipulations of the Convention. Article 37(a) insists on the protection of children against torture or any other form of cruelty, inhumanity or humiliating treatment or chastisement (United Nations 1989).

Oosthuizen, Wolhuter and Du Toit (2003) surveyed methods used by educators to maintain discipline in classrooms and in schools. They distinguished between two major categories of method: retroactive or reactive methods and preventive or proactive methods. Retroactive methods include reprimanding, corporal punishment, detention, extra work, isolation in the classroom, isolation outside the classroom, notifying parents, a point demerit system, due process (i.e. a disciplinary hearing by the school governing body), suspension, expulsion and criminalisation (e.g. laying criminal charges against the learner). Preventive methods, in turn, include a code of conduct, positive discipline, aesthetic and organisational arrangements, thorough knowledge and training on the part of the teacher, paying attention to the organisational culture of the school, and rewarding good behaviour.

From the point of view of educational considerations, preference should, as far as possible, be given to preventive measures (Oosthuizen et al. 2003:466-469). As Bear (in Osher et al. 2010) rightly observes: '... school discipline entails more than punishment. It is complex and includes developing student self-discipline' (original emphasis). However, the particular context will determine the most appropriate course of action. 


\section{Empirical Research Paradigm}

The paradigm of this research was post-positivistic and the research approach was quantitative. A research survey was conducted to determine the trends, attitudes and opinions of the learners in a township secondary school (Creswell 2009:145).

\section{Population and sampling}

The study population consisted of all Grade 10 learners of all the Jouberton secondary schools as well as all the educators teaching Grade 10 learners in the township. A systematic random sample was taken from all the Grade 10 learners of all the secondary schools in the township $(n=509)$. No sample was taken from the educators, because the whole population of educators was used $(n=50)$.

The response rates obtained were good: $98.07 \%$ from the learners and $80.64 \%$ from the educators.

\section{Measuring instrument and data collection procedures}

Closed-ended, structured questionnaires for teachers and learners respectively were drafted with the objective of surveying the application of various methods of dealing with learner misconduct in class and determining the effectiveness of each of the methods. The questionnaires contained a list of 21 possible options for how to maintain discipline. The respondents were to indicate the effectiveness of each method by choosing one of the following options from a Likert-type scale: very ineffective, ineffective, effective, very effective.

\section{Statistical techniques}

The data were captured by the statistical support services of a South African university. Descriptive techniques, including mean scores such as frequencies, were used to categorise the data; inferential techniques were applied to determine the Cronbach alpha coefficient.

\section{Reliability and validity}

During a pilot study six copies of each of the two sets of questionnaires were distributed to both educators and Grade 10 learners. After the questionnaires were corrected and finalised, they were distributed amongst the secondary school teachers and learners. The completed questionnaires were collected at the school.

The internal consistency reliability of the questionnaire was confirmed by applying the Cronbach alpha coefficient. The test-retest reliability of the measuring instrument comes into play in the sense that the same instrument was used frequently, with similar outcomes.

The face validity of the questionnaires is evident in the sense that the content of the questions was clearly directed at the topic of learner misconduct. The questionnaire also meets the norm of content validity in the sense that the content of the questions shows a clear reflection of the various parts or facets of the domain (learner misconduct) under construction. Furthermore, the instrument was subjected to the scrutiny of other researchers with a wide experience in education.

\section{Ethical considerations}

Permission to conduct the research was obtained from the Area Project Office manager of the province's Department of Education. Confidentiality and the anonymity of the respondents were guaranteed. The respondents participated voluntarily; they had the right to withdraw at any stage of the research. Moreover, informed consent was obtained from all of them.

\section{Findings}

Table 1, on the next page, reflects all the major findings.

\section{Discussion}

Teachers' and learners' experiences of the effectiveness of disciplinary measures used at the township school in this study show an interesting pattern. Whereas teachers placed a high premium on non-punitive (positive) discipline strategies, learners indicated that they experience both punitive and non-punitive measures as effective. However, both teachers and learners experienced the following disciplinary measures as effective: a system of classroom rules; proper preparation by the educator; encouraging traditions; encouraging learner pride amongst learners, and discussion or meeting with parents of learners and referral to the principal. Measures found to be least effective by both teachers and learners included: community service; isolation within the classroom; detention, and deprivation of privileges.

The fact that the - educationally more preferred - preventive methods (such as proper preparation by the teacher, positive discipline, rewards and encouraging pride amongst learners) appear at the top of the teachers' hierarchy is heartening and commendable. At the same time, the fact that learners saw the mere invocation of a higher authority (such as referral to the principal, discussion with parents and referral to the school governing body's disciplinary committee), followed by totally discredited forms of maintaining discipline such as corporal punishment, as the most effective ways of maintaining discipline raises concern. Their perception of what is effective discipline is worrisome in view of the fact that several years of democracy have not made a visible difference to the learners' consciousness regarding the relative importance of self-discipline over external forms of discipline. It is little wonder, then, that the majority of the learners (more than 50\%) regarded only referral to the principal and discussions with parents as very effective. That only one preventive method (namely, proper preparation by the teacher) was seen by the majority of teachers as very effective is also cause for concern. 
TABLE 1: Teacher and learner experiences regarding the effectiveness of disciplinary methods.

\begin{tabular}{|c|c|c|c|c|c|c|c|c|}
\hline Question & Method & Person & Ranking & Mean score & Very ineffective (\%) & Ineffective (\%) & Effective (\%) & Very effective (\%) \\
\hline \multirow[t]{2}{*}{1} & \multirow[t]{2}{*}{ Reprimand } & $T$ & 10 & 2.76 & 10.20 & 18.37 & 57.14 & 14.29 \\
\hline & & L & 11 & 2.69 & 26.20 & 16.61 & 19.19 & 38.01 \\
\hline \multirow[t]{2}{*}{2} & \multirow[t]{2}{*}{ Isolation within the classroom } & $\mathrm{T}$ & 19 & 2.17 & 26.67 & 35.56 & 31.11 & 6.67 \\
\hline & & L & 16 & 2.54 & 23.63 & 25.68 & 23.29 & 27.40 \\
\hline \multirow[t]{2}{*}{3} & \multirow[t]{2}{*}{ Isolation outside the classroom } & T & 18 & 2.18 & 25.00 & 38.64 & 29.55 & 6.82 \\
\hline & & L & 13 & 2.62 & 24.31 & 21.18 & 21.88 & 32.64 \\
\hline 4 & Merit-demerit points system & L & 17 & 2.53 & 24.69 & 21.64 & 23.88 & 27.99 \\
\hline \multirow[t]{2}{*}{5} & \multirow[t]{2}{*}{ System of classroom rules } & $\mathrm{T}$ & 5 & 2.94 & 8.16 & 14.29 & 53.06 & 24.49 \\
\hline & & L & 10 & 2.71 & 25.34 & 15.20 & 22.30 & 37.16 \\
\hline \multirow[t]{2}{*}{6} & \multirow[t]{2}{*}{ Positive discipline } & $\mathrm{T}$ & 2 & 3.07 & 6.67 & 11.11 & 51.11 & 31.11 \\
\hline & & L & 15 & 2.60 & 26.55 & 20.00 & 20.34 & 33.10 \\
\hline \multirow[t]{2}{*}{7} & \multirow{2}{*}{$\begin{array}{l}\text { Learner participation in the } \\
\text { compilation of the code of conduct }\end{array}$} & T & 11 & 2.74 & 10.64 & 27.66 & 28.30 & 23.40 \\
\hline & & L & 18 & 2.49 & 27.46 & 22.37 & 23.39 & 26.78 \\
\hline 8 & $\begin{array}{l}\text { Encouraging learner pride amongst } \\
\text { learners }\end{array}$ & L & 9 & 2.71 & 21.52 & 21.19 & 21.19 & 36.09 \\
\hline \multirow[t]{2}{*}{9} & \multirow[t]{2}{*}{ Encouraging traditions } & T & 9 & 2.77 & 11.36 & 20.45 & 47.73 & 20.45 \\
\hline & & L & 8 & 2.71 & 24.31 & 17.01 & 12.18 & 37.50 \\
\hline \multirow[t]{2}{*}{10} & \multirow{2}{*}{$\begin{array}{l}\text { Referring to School Governing } \\
\text { Body's disciplinary committee }\end{array}$} & $\mathrm{T}$ & 15 & 2.44 & 16.28 & 30.23 & 46.51 & 6.98 \\
\hline & & L & 7 & 2.72 & 22.92 & 17.61 & 23.59 & 35.88 \\
\hline \multirow[t]{2}{*}{11} & \multirow{2}{*}{$\begin{array}{l}\text { Discussion or meeting with parents } \\
\text { of learners }\end{array}$} & T & 4 & 2.98 & 9.62 & 15.38 & 42.31 & 32.69 \\
\hline & & L & 1 & 3.07 & 15.53 & 13.59 & 18.77 & 52.10 \\
\hline \multirow[t]{2}{*}{12} & Emphasising values & $\mathrm{T}$ & 8 & 2.82 & 6.12 & 20.41 & 59.18 & 14.29 \\
\hline & & L & 14 & 2.60 & 22.91 & 22.91 & 24.73 & 29.45 \\
\hline 13 & Regular prayers by educators & T & 14 & 2.57 & 18.18 & 18.18 & 52.27 & 11.36 \\
\hline & & L & 5 & 2.79 & 25.58 & 12.62 & 1.94 & 42.86 \\
\hline 14 & Proper preparation by the educator & $\mathrm{T}$ & 1 & 3.34 & 6.00 & 8.00 & 32.00 & 54.00 \\
\hline & & L & 3 & 2.92 & 16.39 & 16.72 & 24.41 & 42.47 \\
\hline 15 & Reward & T & 3 & 3.02 & 8.16 & 12.24 & 48.98 & 30.61 \\
\hline & & L & 21 & 2.31 & 33.59 & 22.14 & 23.66 & 20.`61 \\
\hline 17 & Community service & $\mathrm{T}$ & 20 & 2.14 & 29.73 & 35.14 & 27.03 & 8.11 \\
\hline & & L & 20 & 2.35 & 24.07 & 20.37 & 21.11 & 24.44 \\
\hline 18 & Extra work & $\mathrm{T}$ & 12 & 2.73 & 8.89 & 24.44 & 51.11 & 15.56 \\
\hline & & L & 4 & 2.92 & 20.83 & 12.50 & 20.14 & 46.53 \\
\hline 19 & Detention & $\mathrm{T}$ & 16 & 2.35 & 25.00 & 25.00 & 40.00 & 10.00 \\
\hline & & L & 19 & 2.47 & 28.62 & 22.68 & 21.56 & 27.14 \\
\hline 20 & Corporal punishment & $\mathrm{T}$ & 21 & 2.03 & 45.95 & 18.92 & 21.62 & 13.51 \\
\hline & & L & 6 & 2.78 & 19.86 & 19.50 & 23.05 & 37.59 \\
\hline 21 & Refer to principal & $\mathrm{T}$ & 7 & 2.85 & 10.87 & 19.57 & 43.48 & 26.09 \\
\hline & & L & 2 & 3.04 & 18.89 & 10.74 & 17.04 & 53.33 \\
\hline
\end{tabular}

$\mathrm{T}$, teacher; L, learner.

Discipline at schools, at least as far as the sample of schools included in this study is concerned, is far from sound: discipline problems more serious than the international norm dominate. Whilst disruptive behaviour (frequently the most common form of misconduct faced by teachers internationally) is experienced daily by almost half of the teachers surveyed, $58 \%$ of them indicated that they had to deal with the more serious problem of absenteeism daily. To a great extent, these problems have a serious effect on the teachers' family life, personal health, job satisfaction and morale. Whereas teachers commendably prefer the educationally sound preventive and positive methods of maintaining discipline, these methods appear not to be very effective, as shown by the low ranking they were given by both teachers and learners. It seems as if teacher education in maintaining discipline - particularly the successful application of proactive methods - is falling short.

\section{Recommendations}

Whether the discrepancy between teachers' and learners' views of the effectiveness of some disciplinary measures is true only of township school teachers and learners or should be seen as common amongst learners and teachers across all school types in South Africa and beyond should be investigated by further research. Considering the relatively serious levels of ill discipline - at least in the township schools included in the sample of this study - programmes based on positive discipline which merit drastic intervention (such as that developed by Michael Epstein and colleagues at the University of Lincoln, Nebraska, United States of America [Epstein et al. 2008]) should be pilot tested at South African schools and the effects of such programmes should be subjected to further research. 
Follow-up qualitative research aimed at determining the exact nature of this lacuna and ways of addressing it and ameliorating the situation is recommended. Finally, the learners' views on the maintenance of discipline constitute an alarming indictment of the principles of democracy, human rights and human dignity, and of rationality as a tool of conflict resolution. These views, their origins and how to change them should also be the subject of research.

The comparison between teachers' and learners' views on the incidence of various forms of misbehaviour, and on the effectiveness of methods used to maintain discipline is based only on aggregate data. A statistical comparison at the individual level - for instance, to see how the responses of the learners correlate with those of the teachers - might be a valuable follow-up study.

\section{Conclusion}

The experiences of both teachers and learners as surveyed point to a discipline situation at the school that is far from satisfactory. Furthermore, problems with discipline are more serious than the international norm indicates. These problems have a serious effect on a large part of the teachers' family life, personal health, job satisfaction and morale. Whilst both teachers and learners commendably prefer the educationally sound preventive and positive methods of maintaining discipline, the application of these methods appears not to be effective: it seems as if teacher education is falling short in the area of maintaining discipline, particularly regarding the successful application of proactive methods of doing so. Finally, the learners' views on the maintenance of discipline are an alarming indictment of the principles of democracy, human rights and human dignity, and of rationality as a tool for conflict resolution. Follow-up qualitative research is recommended that aims at determining the exact nature of this lacuna and ways of addressing it and ameliorating the situation.

\section{Acknowledgements Competing interests}

The authors declare that they have no financial or personal relationship(s) that may have inappropriately influenced them in writing this article.

\section{Authors' contributions}

N.J.S. (North-West University), I.J.O. (North-West University), C.C.W. (North-West University) and C.B.Z. (North-West University) contributed equally to the writing of this article.

\section{References}

Barclay, W., 1974, New Testament words, John Knox Press, Louisville.

Barclay, W., 1976, The letters to the Hebrews, John Knox Press, Louisville.

Betteridge, H.T., 1978, s.v. 'bergen', in Cassell's German-English dictionary, Cassell and Co., London, p. 78.

Butterfield, J., 2003, s.v. 'discipline', in Collins English dictionary, 6th edn., HarperCollins Publishers LLC, London, p. 472.

Creswell, J.W., 2009, Research design, Sage Publishers, Los Angeles.

Department for Education, England and Wales, 2011, Ensuring good behaviour in schools: A summary for heads, governing bodies, teachers, parents and pupils, Her Majesty's Stationery Office (HMSO), London.

De Wet, C. \& Jacobs, L., 2009, 'An exploratory study on learner misbehaviour in Lesotho', Journal for Educational Studies 8(2), 52-73.

Epstein, M., Atkins, M., Cullinan, D., Kutash, K. \& Weaver, K., 2008, Reducing problems in the elementary school classroom, Institute of Education Research, University of Lincoln-Nebraska, Lincoln.

Grootman, M.E., 2003, 'How to teach your children discipline', in Kidsource online, viewed 12 June 2012, from http://www.kidsource.com/kidssource/content/ viscipline.3.19.html

Heidegger, M., 2005, Off the beaten track, Cambridge University Press, Cambridge.

Keller, C., 2011, 'Vandalism falls, but schools still count the costs', in The Advertiser, viewed 30 April 2012, from http://www.adelaidenow.com.au/news/in-depth/ vandalism-falls-but-schools-still-count-the-costs/story-e6frebvu-1226033865016

Mabeba, M.Z. \& Prinsloo, E., 2000, 'Perceptions of discipline and ensuing discipline problems in secondary education', South African Journal of Education 20(1), 34-41.

Morin, J. \& Battalio, R., 2004, 'Construing misbehaviour', Journal of Positive Behaviour Interventions 6(4), 251-254. http://dx.doi.org/10.1177/10983007040060040601

Oberholzer, C.K., 1968, Prolegomena van prinsipiële pedagogiek, HAUM, Cape Town.

Oosthuizen, I.J. Botha, P., Roos, M.C., Rossouw, J.P. \& Smit, M.H., 2009, Aspects of education law, Van Schaik, Pretoria.

Oosthuizen, I.J., Wolhuter, C.C. \& Du Toit, P., 2003, 'Voorkomende of bestraffende maatreëls in Suid-Afrikaanse skole: Watter benadering moet voorkeur geniet?', Koers - Bulletin for Christian Scholarship 68(4), 457-479.

Osher, D., Bear, G.G., Sprague, J.R. \& Doyle, W., 2010, 'How can we improve discipline?', Educational Researcher 39(1), 48-58. http://dx.doi.org/10.3102/0013189X09357618

Renn, S.D., 2005, s.v. 'yasar', 'musar', Expository dictionary of Bible words, Hendrickson Publishers, Peabody, pp. 174, 285.

Russo, C.J., Oosthuizen, I.J. \& Wolhuter, C.C., 2013, Best practices for student misconduct in six countries, Littlefield and Rowman, New York.

Scholze-Stubenrecht, W., Sykes, J.B., Clark, M. \& Thyen, O. (eds.), 2005, s.v. 'geborgenheit', in Oxford German dictionary, Oxford University Press, Oxford, p. 721.

Shen, J., Zhang, N., Zhang, C., Richardson, K. \& Shatzer, R.H., 2009, 'Chinese elementary school teachers' perceptions of students' classroom behavioural problems', Educational Psychology: An International Journal of Experimental Educational Psychology 29(2), 187-201.

South Africa, 1996(a), Constitution of the Republic of South Africa, Act 108 of 1996, Government Printer, Pretoria.

South Africa, 1996(b), South African Schools Act, Act 84 of 1996, Government Printer, Pretoria.

South African Human Rights Commission (SAHRC), 2008, Report on school based violence, South African Human Rights Commission, Pretoria.

Strong, J., 1995, The new Strong's exhaustive concordance of the Bible, Thomas Nelson Publishers, Nashville.

United Nations, 1989, Universal Declaration on the Rights of the Child, United Nations, New York.

Upindi, N.M., 2012, 'Views of teachers and parents regarding factors that contribute to learners' indiscipline in secondary schools: A case of selected schools in the Khomas Education Region', M.Ed. thesis, Department Educational Foundations and Management, University of Namibia.

Vines, W.E., 1985, Vine's expository dictionary of biblical words, Thomas Nelson Publishers, Nashville.

Wolhuter, C.C., Oosthuizen, I.J. \& Van Staden, J.G., 2010, 'Skoolfase/leerderouderdom as faktor in leerderdissipline in Suid-Afrikaanse skole [School phase/student age as a factor in student discipline in South African schools]', Tydskrif vir Christelike Wetenskap 46(1), 169-186.

Wolhuter, C.C. \& Steyn, S.C., 2003, 'Learner discipline at school: A comparative educational perspective', Koers - Bulletin for Christian Scholarship 68(4), 521-538.

Wolhuter, C.C. and Van Staden, J.G., 2008, 'Bestaan daar 'n dissiplinekrisis binne SuidAfrikaanse skole? Belewenis van opvoeders [Is there a discipline crisis in South African schools? Experience of educators]', Tydskrif vir Geesteswetenskappe 48(3), 389-398. 